\title{
A Systematic Literature Review of the Potential Therapeutic Effects of Ayahuasca Tea Prepared From the Use of Banisteriopsis Caapi and Psychotria Viridis
}

\author{
Adriane Cordeiro Trevisani \\ Post-Graduate Program in Animal Science with Emphasis on Bioactive Products, \\ Universidade Paranaense \\ Pç Mascarenha de Morais, 4282, Umuarama, PR, CEP: 87502-210 \\ E-mail: adrianereunidos@hotmail.com \\ João Pedro Cordeiro Trevisani \\ Department of Medicine, Universidade Federal do Paraná \\ Rua XV de Novembro, 1299 - Centro, Curitiba - PR, 80060-000 \\ E-mail: joaopedro01378@gmail.com
}

Moacir Haverroth

Department of Medicinal, Aromatic, Condiment and Ornamental Plants, EMBRAPA

Rodovia BR 364, Km 14 - Distrito Industrial, Rio Branco - AC, 69920-900

E-mail: moacir.haverroth@embrapa.br

Ailton da Cruz Melo

Department of Microbiology, Universidade Paranaense

Pç Mascarenha de Morais, 4282, Umuarama, PR, CEP: 87502-210

E-mail: ailton.melo@edu.unipar.br

Isabela Carvalho dos Santos

Post-Graduate Program in Animal Science with Emphasis on Bioactive Products,

Universidade Paranaense 
Pç Mascarenha de Morais, 4282, Umuarama, PR, CEP: 87502-210

E-mail: isabela_carvalhoxd@hotmail.com

\author{
Lidiane Nunes Barbosa \\ Post-Graduate Program in Animal Science with Emphasis on Bioactive Products, \\ Universidade Paranaense \\ Pç Mascarenha de Morais, 4282, Umuarama, PR, CEP: 87502-210 \\ E-mail: lidianebarbosa@prof.unipar.br
}

Daniela Dib Gonçalves (Corresponding author)

Post-Graduate Program in Animal Science with Emphasis on Bioactive Products, Universidade Paranaense

Pç Mascarenha de Morais, 4282, Umuarama, PR, CEP: 87502-210

E-mail: danieladib@prof.unipar.br

Received: Nov. 3, 2020

Accepted: Dec. 2, 2020

Published: Dec. 10, 2020

doi:10.5296/jas.v9i1.17910

URL: https://doi.org/10.5296/jas.v9i1.17910

\begin{abstract}
Ayahuasca is a drink of indigenous origin made as a decoction obtained from medicinal plants found mainly in Acre, state of Brazil, which are the leaves of Psychtoria viridis, popularly known as "chacrona" in Brazil, and the stem of Banisteriopsis caapi, commonly known as mariri or jagube. The decoction is used in religious practices for the therapy of diseases that affect the human being, such as psychological disorders, neurological, parasitic and bacterial infections. Considering the existing bioactive compounds and the therapeutic potential of ayahuasca, this study aims to carry out a literature review of scientific articles (PubMed, Scielo and LILACS) in order to gather knowledge within 30 years of study about the therapeutic potentials of ayahuasca. In the current literature, the studies focus on the area of neuropsychology, dealing with ayahuasca as a form of therapy for neurological and neuromotor disorders. In addition, antimicrobial, antiparasitic, immunomodulatory, and antioxidant actions have already been reported. However, new studies are still needed in these areas in order to evaluate the efficacy and safety of ayahuasca and its component plant species, in order to use it as an alternative therapy, especially in the population from which the traditional knowledge about this beverage came from.
\end{abstract}


Keywords: Chacrona, Banisteriopsis caapi, Psychotria viridis, phytotherapy, mariri, medicinal plants

\section{Introduction}

Medicinal plants are defined as plants that have components with therapeutic properties or drug precursors and have been adopted as a medicinal base since the beginning of civilizations and are distributed worldwide, with considerable economic, clinical, and pharmaceutical importance until today (World Health Organization, 1998).

Traditional knowledge about medicinal plants may be found in cultural practices of native peoples, such as those of indigenous origin, whose use of natural resources provides information about these plants (Ferreira and Osório, 2007).

Some pre-Columbian indigenous groups in the Amazon region perform an ancient ritualistic practice associated with shamanism (a set of rituals using psychoactive substances) using the popularly known ayahuasca tea, a drink composed of two plant species, Banisteriopsis caapi and Psychotria viridis.

The native species Banisteriopsis caapi (Spruce ex Griseb.), popularly known as mariri or jagube, described in the botanical family Malpighiaceae is a liana or climbing plant, being found mainly in northern Brazil, in the states of Acre, Amazonas, Pará, and Rondônia, but may also occur in Mato Grosso, a state that belongs to the central-western region (Mamede, 2015).

The native species Psychotria viridis (Ruiz \& Pav), is described as a shrub belonging to the Rubiaceae family with geographical dominance in Acre and Amazonas, regions where it is more popularly known as chacrona. This species is also found in the southeast region of Brazil (Taylor, Gomes and Zappi, 2015).

Ayahuasca is a drink prepared by decoction or cold aqueous extraction of the B. caapi stem fibres and the leaves of $P$. viridis. These components are previously sanitized through the washing, crushed, and placed in layers inside a container with a volume of approximately 40 litres. The number of components and the volume of water used in the preparation of the drink varies according to the religious groups and the occasion of the preparation ritual (such as a concentration of $50 \%$ mariri and $50 \%$ chacrona, or $70 \%$ mariri and $30 \%$ chacrona) (Garrido and Sabino, 2009).

With the wide religious practice and use of the therapeutic properties of the decoction by these native peoples, its use has been spread throughout Brazil and other countries, using its characteristics in practices of religious groups and also in treatments, mainly in the treatment of chemical dependents (Brierley and Davidson, 2012).

In order to preserve and value the traditional knowledge of natural resources and cultural practices of native Brazilian peoples, the Brazilian federal government has established policies that encourage research and use of plants with therapeutic characteristics. An example of this initiative is the Decree 5813/2006, which has approved the National Policy on Medicinal Plants and Plant Therapies, ensuring access to knowledge about medicinal, psychoactive, and herbal plants, as well as their safe use (Brasil, 2006a). 
In 1971 an international treaty on the control of psychotropic substances was signed in Vienna, Austria. Ayahuasca is not under the control of this treaty and its lawful use is determined according to each country (UNODC, 2013). In the United States, for example, the use of ayahuasca is restricted to religious practices and clinical research only with the authorization of the US government, since the N,N-dimethyltriptamine (DMT) found in the decoction fits in the first scale of controlled substances (McKenna, 2004; United States, 2019). Due to the presence of the same substance, ayahuasca is classified as a class A drug in the United Kingdom, being illegal in the country by the Drug Abuse Act signed in 1971 (Cahal, 1974).

Countries such as Netherlands Sweden, and Norway also consider ayahuasca as a narcotic, due to the presence of the DMT component in the decoction, being illegal its preparation, use, distribution, and sale, although allowed for use in religious practices (Netherlands, 1928; Norge, 2013; Sweden, 1968).

On the other hand, the Italian Ministry of Health declared ayahuasca as a non-narcotic substance in 2010 (Vetrulli, 2011). And Spain only prohibited the sale of the decoction due to its toxicity (España, 2004). In Portugal, only the possession and consumption of ayahuasca are not considered illegal, as with other drugs, according to Law 30 of 2000 (Portugal, 2000).

In Latin America, similarly to Portugal, Uruguay also allows the possession and use of ayahuasca according to Law No. 17.016 of 1998 (Uruguay, 1998). However, in Argentina, according to Law $\mathrm{n}^{\circ} 19.303$, signed in 1971, ayahuasca is considered illegal due to the presence of harmaline and DMT in the decoction (Argentina, 1971).

Currently, there is research that seeks to know and elucidate the different therapeutic potentialities of ayahuasca, highlighting not only the neuropsychological effects, but also antimicrobial, antiparasitic, and antioxidant properties, among others. Thus, this work aims to highlight the main therapeutic characteristics of ayahuasca decoction through a literature review.

\section{Material and Methods}

This systematic literature review was carried out using databases of scientific articles (PubMed, Scielo and LILACS) in order to compile the knowledge of 20 years of study about the Ayahuasca drink and its possible therapeutic effects. The descriptors Ayahuasca, "Banisteriopsis caapi", "Psychotria viridis", "Plant Extracts", or "Plant Preparations", and the filters: last 20 years (1997-2018); abstract available. The inclusion criteria used were: articles published in English, Portuguese or Spanish, mentioning in the title and / or summary the therapeutic effects found through the use of Ayahuasca prepared from Banisteriopsis caapi and Psychotria Viridis The exclusion criteria were: articles published as a systematic review or revision; case reports; letters; editorial; news; guidelines; interviews; note; errata; and articles with secondary data, in order to focus exclusively on articles that contemplate the use of ayahuasca as a therapeutic resource. 


\section{Results and Discussion}

\section{Indigenous traditional knowledge}

The use of medicinal plants by indigenous communities as a therapeutic source for the treatment of diseases has been going on for centuries and their knowledge of these natural resources in the maintenance and preservation of human life, are one of the oldest forms of medicinal practice for humanity. Regular knowledge about different species of plants for therapeutic purposes is currently widely studied by modern science in order to develop new forms of natural treatments in order to guarantee a safe and effective use of natural compounds based on their empirical knowledge (Meneguelli et al., 2020).

Regarding especially the traditional knowledge of medicinal plants and the availability of this resource in the Brazilian Unified Health System (SUS), reaching a large number of people, the National Policy of Integrative and Complementary Practices (PNPIC) and the National Policy of Medicinal Plants and Phytotherapies (PNPMF) were implemented. These policies were published in 2006, aiming to increase the use of natural resources in health care with high safety and effectiveness (Brasil, 2006a, 2006b). Although the National Health Surveillance Agency (ANVISA) determined in 2014 by the Resolution No. 26 of the Collegiate Board of Directors that the species Banisteriopsis caapi cannot be used in herbal products, its research and utilization in religious practices that use the drink ayahuasca is allowed and widely explored (Brasil, 2014).

In this way, the indigenous culture has consolidated the national use and international recognition of ayahuasca decoction.-

\section{Banisteriopsis caapi [(Spruce ex Griseb.) C.V. Morton]}

There are several reports in the literature about investigations of the pharmacological effects of this species, used separately from $P$. viridis or with the isolation of its phytochemical constituents, the seven $\beta$-carbolin alkaloids: harmine; harmaline; harmol; tetrahydronorharmine (THNH); tetrahydroharmine (THH) banistenoside A and banistenoside $\mathrm{B}$, and the two proanthocyanidins: epicatechin and procyanidine B2. The bioactive compounds harmine, harmaline and tetrahydroharmine inhibit monoamine oxidase (MAO), while the two proanthocyanidins also produce antioxidant effects in the body (Wang et al., 2010).

A study revealed that the carbolin type- $\beta$ alkaloids found in $B$ caapi presented in vitro antimicrobial effects with minimal inhibitory concentration (MIC), characterizing inhibitory action against Escherichia coli (control of amoxicillin with MIC of $8 \mu \mathrm{g} / \mathrm{mL}$ ) and Staphylococcus aureus (control of tetracycline with MIC of $0.25 \mu \mathrm{g} / \mathrm{mL}$ ) in concentrations of $62.5 \mu \mathrm{g} / \mathrm{mL}$ and $1000 \mu \mathrm{g} / \mathrm{mL}$, respectively (Bussmann et al., 2010). Alkaloids may still act as antitumor and have an auxiliary effect on blood circulation (Chen et al., 2005; Shi, Liao and Chen, 2001).

In a clinical study by Schwarz et al. (2003), the action of MAO-A inhibitors presents in Banisteriopsis caapi exhibited a neuroprotective effect, acting as clorgiline, and might be used by patients with degenerative diseases such as Parkinson and Alzheimer. Another study 
showed in vitro inhibition of MAO-A and MAO-B, as well as a potent antioxidant action (Samoylenko et al., 2010). In another recent study, performed by Fisher et al. (2018), only the Banisteriopsis caapi species was used in the preparation of the beverage, given to marmosets, and the results revealed a mild antiparkinsonian action of the chemical components found in this plant.

Among other neurological benefits already mentioned, it was possible to show improvements in attention in a study in which 25 participants of the rituals were evaluated before and 24 hours later with questionnaires based on the Five Facets of Attention (FFMQ), which detected improvement in the facets of observation, attention, and reduction of judgment. (Soler et al., 2015).

In another study that performed a chemical screening in vitro against protozoans, the bioactive compound harmine, an alkaloid present in B. caapi species, showed activity against Trypanosoma lewissi and Trypanosoma cruzi, with 70\% growth inhibition after 96 hours, which explains the indigenous medicinal use of this decoction against malaria and other possible parasites (Pomilio et al., 1999).

\section{Psychotria viridis (Ruiz \& Pav)}

Given the wide use of this plant in the form of decoction associated with other plant species, its pharmacological effects are currently being clarified and scientifically proven. In its phytochemical analysis, a mixture of the following substances was found: long chain hydrocarbons; 24-methylene-cycloarthenol; squalene; $\beta$-sitosterol; stigmasterol; triacilglycerol; nonacosanal; nonacosanol; entriacontanoic acid; hexadecanoic acid; heptadecanoic acid; ursolic acid; oleanolic acid; 1-palmythoyl glycerol or monopalmitin were

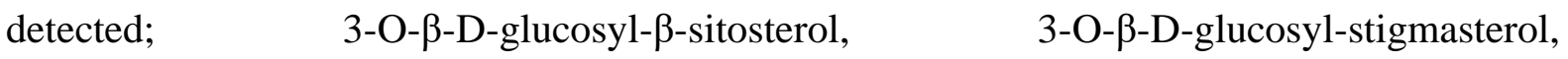
4-methyl-4-epi-quinate and methyl tetradecanoatotamine; N-methiltriptamine; $\mathrm{N}, \mathrm{N}$-dimethyltriptamine (DMT), with DMT standing out as an acetylcholinesterase inhibitor, showing itself as a promising complementary treatment for Alzheimer. Further, the DMT inhibition of tumor cells B16F10 and 4T1 was evidenced in a study (Soares et al., 2017). DMT also inhibits MAO, if administered via parenteral, since it is metabolized in the gastrointestinal tract if not ingested together with $\beta$-carbolins, such as harmine, harmaline or tetrahydoharmaline (Tupper, 2008).

In a study that obtained methanolic extract from Psychotria viridis leaves, the action of DMT and tryptamine compounds present in the extract was evaluated. They were analyzed separately and tested against Gram-positive and Gram-negative microorganisms, presenting antibacterial action. This study also revealed the inhibitory capacity of the enzyme acetylcholinesterase and the cellular viability only of the tryptamine compound, which is a precursor of the DMT substance (Soares, 2015).

\section{Ayahuasca: Ritual use}

Ayahuasca, popularly known by the names caapi, daime, yajé, natema, vegetal and hoasca, is a decoction composed by the association of two plants: the stem of Banisteriopsis caapi and the leaves of Psychotria viridis. Originally, they were used by indigenous groups in rituals 
associated with shamanism and by healers who practiced popular medicine based on plant resources (Santos, Moraes and Holanda, 2006; Tupper, 2002).

In Brazil, the use of Ayahuasca in religious rituals in different regions and also in non-indigenous populations has spread and its use for religious purposes is legal, supported by the National Anti-Drug Council, through the Resolution of November 4, 2004 (Brasil, 2004). The most important Brazilian religious groups that regularly use the drink are Santo Daime, União do Vegetal (UDV) and Barquinha, which emerged in the Amazon region and spread throughout Brazil (Labate, 2004).

From Brazilian religious groups the use of ayahuasca spread around the world and its use is already reported in several countries such as: Peru, Bolivia, Colombia, Venezuela, and Ecuador. In the last years it has been established in the United States and in some European countries, including Germany, England, Netherlands, France and Spain (Tupper, 2008; Uthaug et al., 2018). In these countries, the ritualistic use of this decoction in the treatment of chemical dependence is already provided, being an alternative therapeutic approach with much acceptance by the population (Brierley and Davidson, 2012).

According to Loizaga-Velder and Verres (2014), its use in the clinical therapy of chemical dependent patients may be an effective form of treatment, since the results found are promising. This effect against chemical dependency has been shown, for example, in patients considered crack addicts (Cruz and Nappo, 2018).Other studies conducted in different countries such as Canada, Italy, and the Czech Republic also evaluated the therapeutic potential in chemical dependents (Horák, Hasíková and Verter, 2018; Talin and Sanabria, 2017; Thomas et al., 2013) and in other neurological disorders, as observed in the study by Lafrance et al. (2017). This study revealed a potential action of ayahuasca in the treatment of eating disorders.

Ayahuasca presented therapeutic effects on chemical dependents, such as improved self-esteem, social and emotional awareness, a feeling of hope and empowerment, and reduced desire for drug use. Other neuropsychological and neuromotor effects (against disorders such as depression, Parkinson, Alzheimer, among others) have already been observed, as in the study by Barbosa et al. (2016), which showed a drop in depression and alcohol use scores. However, there are limitations in existing studies that clarify the therapeutic action of these factors, since Ayahuasca is used in a ritualistic environment, where religious and cultural issues are involved in the process of reestablishing health, and controlled clinical studies are necessary to confirm possible actions (Nunes et al., 2016).

In the study by Santos et al. (2018) with 17 patients with a history of depression and resistance to conventional treatment, antidepressant effects were evidenced in the use of ayahuasca, in which the symptoms decreased for about 2 to 3 weeks. Osório et al. (2015) also showed an anti-depressant effect of the Ayahuasca decoction in clinical studies on six volunteers who had mild symptoms of depression, and observed that after the use of the decoction the depressive symptoms diminished in the first 24 hours and the effect continued for 21 days.

The potential antidepressant effects of ayahuasca may be observed in studies in other countries (Palhano-Fontes et al., 2018), such as the study of ritual participants in Colombia and 
Netherlands, in which they were evaluated with questionnaires one day before the rituals, and four weeks later, reporting an improvement in cognitive thinking and affection (Uthaug et al., 2018).

Due to the wide ritualistic use of the ayahuasca decoction and its evident effects on the human organism, the chemical components from the two plant species used in the drink has been investigated in recent years. These studies tried to prove scientifically the therapeutic potential of these species, although a large part of them have focused on the neuropsychological effects of the drink.

\section{Chemical Composition and Pharmacological Action of Ayahuasca}

The combination of these two plant species results in a synergistic effect, since Banisteriopsis caapi has in its stem the $\beta$-carbolin alkaloids: harmaline (HRL), harmine (HRM) and tetrahydro-harmine (THH), reversible enzyme inhibitors (MAO) and the species Psychotria viridis, popularly known as chacrona or queen leaf, contains in its leaves monoamine dimethyltriptamine (DMT). This is a potent hallucinogen, also metabolized by MAO. Thus, the ingestion of the beverage elaborated by decoction results in the increase of serotonin levels, inhibits the MAO, preventing the metabolization of DMT by the enzyme, which makes this alkaloid available orally, resulting in a hallucinogenic effect (Callaway and Grob, 1998; Santos et al., 2007).

Alkaloids present in decoction (harmine, harmaline, tetrahydroharmine, harmol, N,N-dimethyltriptamine, N-methyl-1,2,3,4-tetrahydrobeta-carboline) (McIlhenny et al., 2009), especially tryptamine (precursor of DMT), presents antibacterial action. They inhibit the growth of bacteria such as Staphylococcus aureus, Bacillus cereus, Escherichia coli, Klebsiella oxytoca, and Klebsiella pneumoniae, so that with the methylation of tryptamine (becoming DMT) there was a reduction of antibacterial action in these species (Soares, 2015). These alkaloids also act in gastrointestinal infestations, inhibiting the growth of helminth and protozoan parasites that cause malaria, leishmaniasis, Chagas disease, toxoplasmosis, and trypanosomiasis (Callaway et al., 2005).

In a study carried out in mice on the effects of harmaline, a substance present in Ayahuasca, in the treatment of anxiety through the animal model of elevated plus-maze, it was found that this alkaloid had a direct interference in the behavior of anxiety, where the administration of harmalina in lower doses, developed anxiogenic effects, while higher doses produced anxiolytic effects. Another study in rats also investigated the potential for anxiolytic activity of harmaline using an animal model of obsessive-compulsive disorder (OCD), and it was found that animals treated with harmaline also demonstrated anxiolytic action of this alkaloid.

The same bioactive compounds represent a natural source from medicinal plants and present a powerful action in the fight against free radicals with antioxidant effects and immunomodulatory potentials (Moura et al., 2007; Szabo et al., 2014) study conducted at the University of São Paulo showed an immunomodulatory action of lymphocytes, with potential action on inflammatory mediators, in which there was a decrease in the percentage of CD3 and CD4 lymphocytes and an increase in NK (natural killer) cells, acting as a sympatomimetic drug. 
(Santos et al., 2011).

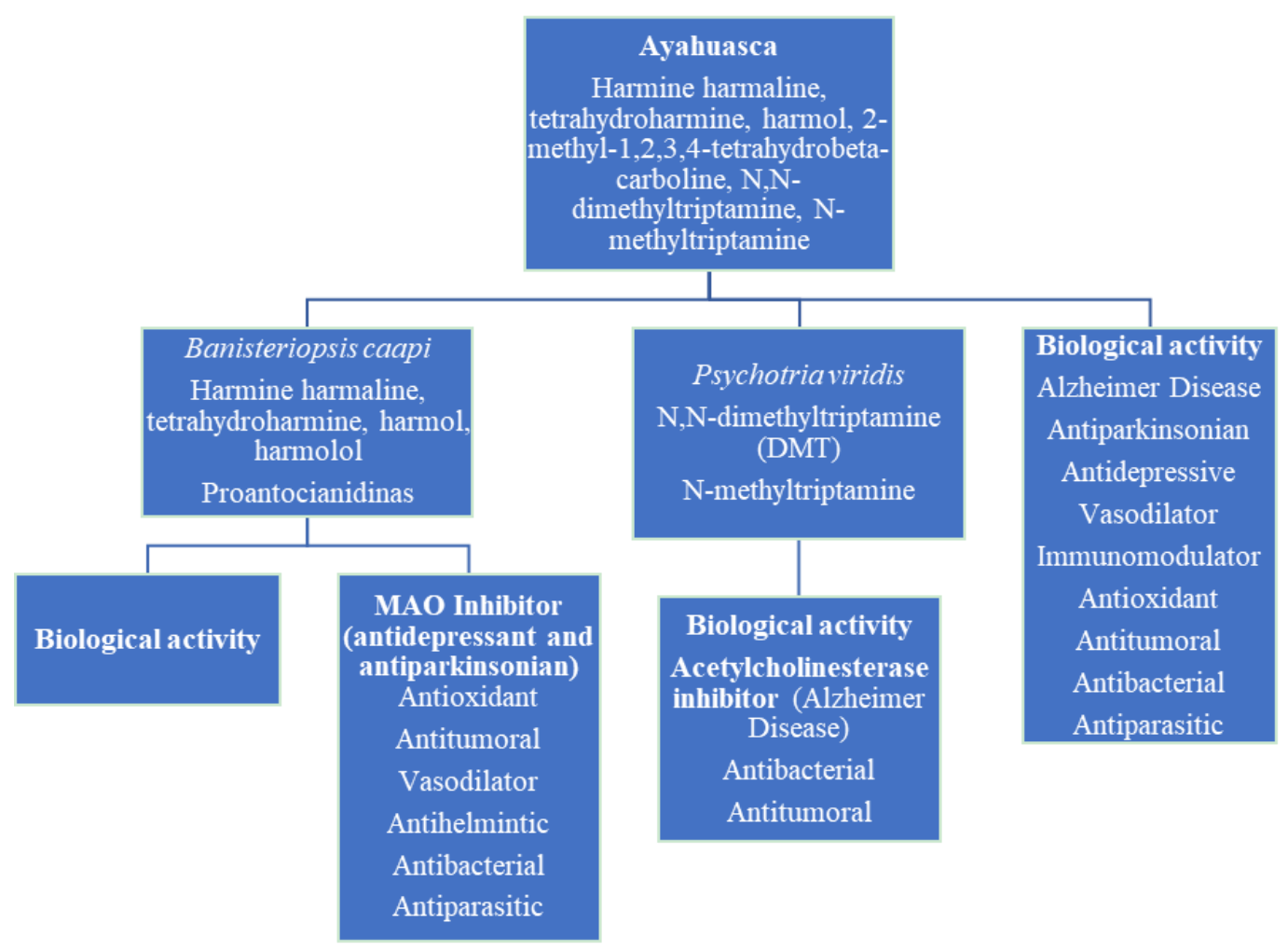

Figure 1. Represents the therapeutic effects found in B. caapi and P. viridis, plants that are components of ayahuasca

Figure 1 represents the effects found on the two component plants of ayahuasca, as well as on the decoction itself. The Table 1 reports some articles published in the period 1997-2018, referring to the therapeutic effects of ayahuasca, as well as the results of the investigations. Is can see that most of the studies present in this table make use of interviews or questionnaires in order to evaluate the effects after the passage of the participants through the ritual of using the drink. In vitro tests use mainly alcohol extracts from plants (Table 1).

Figure 1: effects found on the two component plants of ayahuasca, as well as on the decoction itself. 
Table 1. Different therapeutic actions of ayahuasca in the period 1997-2018.

\begin{tabular}{|c|c|c|c|}
\hline Author & Title & Methodology & Results \\
\hline $\begin{array}{c}\text { Pomilio et al., } \\
1999 .\end{array}$ & $\begin{array}{l}\text { Ayahuasca: an experimental } \\
\text { psychosis that mirrors the } \\
\text { transmethylation hypothesis of } \\
\text { schizophrenia. }\end{array}$ & $\begin{array}{l}\text { DMT levels in the } \\
\text { urine of volunteers } \\
\text { before and after } \\
\text { ayahuasca } \\
\text { consumption and its } \\
\text { biological effects } \\
\text { were assessed. }\end{array}$ & $\begin{array}{c}\text { Hallucinogenic } \\
\text { compounds were detected } \\
\text { in the urine of the } \\
\text { volunteers and } \\
\text { psychological and } \\
\text { anti-tripanosomal effects } \\
\text { were observed. }\end{array}$ \\
\hline $\begin{array}{c}\text { Schwarz et al., } \\
2003 .\end{array}$ & $\begin{array}{l}\text { Activities of extract and } \\
\text { constituents of Banisteriopsis caapi } \\
\text { relevant to parkinsonism. }\end{array}$ & $\begin{array}{l}\text { B. caapi extracts } \\
\text { were tested in mice } \\
\text { livers to assess MAO } \\
\text { inhibition. }\end{array}$ & $\begin{array}{l}\text { The extract and the } \\
\text { harmaline showed } \\
\text { MAO-A inhibition } \\
\text { (concentration-dependent), } \\
\text { but low MAO-B inhibition } \\
\text { activity. }\end{array}$ \\
\hline $\begin{array}{c}\text { Chen et al., } \\
2005 .\end{array}$ & $\begin{array}{c}\text { Antitumor and neurotoxic effects of } \\
\text { novel harmine derivatives and } \\
\text { structure-activity relationship } \\
\text { analysis }\end{array}$ & $\begin{array}{l}\text { Harmonin-derived } \\
\text { compounds were } \\
\text { tested in mice with } \\
\text { lung cancer }\end{array}$ & $\begin{array}{l}\text { Some derived compounds } \\
\text { induced apoptosis of } \\
\text { tumor cells, with a tumor } \\
\text { inhibition rate of } 15.3 \text { to } \\
49.5 \% \text {. }\end{array}$ \\
\hline
\end{tabular}

Moura et al., Antioxidant properties of $\beta$-carbolin 2007. alkaloids are related to their antimutagenic and antigenotoxic activities.

Samoylenko et Banisteriopsis caapi, a unique al. 2010. combination of MAO inhibitory and antioxidative

constituents for the activities relevant to neurodegenerative disorders and

Parkinson's disease.

Bussman et al., Minimum inhibitory concentrations 2010. of medicinal plants used in Northern Peru as antibacterial remedies.

Oliveira et al., Neurobehavioral, reflexological and 2011. physical development of Wistar rat offspring exposed to ayahuasca during pregnancy and lactation.
Beta-carbolins were tested using strains of S. cerevisae deficient and proficient in oxidative defenses.

The chemical profile of B. caapi aqueous extract was

performed and its antioxidant,

cytotoxic, MAO

inhibition, and

acetylcholinesterase activities were evaluated.

The antimicrobial activity of the aqueous and ethanolic extracts from 141 plant species was tested, including B. caapi.

Ayahuasca doses were used on Wistar rats and their offspring to assess the effects of perinatal exposure to the beverage with
Beta-carbolin alkaloids promoted the survival of wheat cells with their antioxidant properties, besides clearing hydroxyl radicals.

The harmine showed MAO-A and MAO-B inhibition. Epicatechin and procyanidin B2 showed strong antioxidant activity and moderate MAO-B inhibition.

It was possible to detect an inhibitory action against E. coli and S. aureus at concentrations of 0.0625 $\mathrm{mg} / \mathrm{mL}$ and $1 \mathrm{mg} / \mathrm{mL}$, respectively.

Effect upon MAO of adult rats was observed, but no statistically significant results were found in the offspring.
Conclusion

Ayahuasca

compounds are considered

psychometric and neuroendocrine.

The results provide the basis for the usefulness of B. caapi extract in the treatment of

Parkinson's disease. The findings indicate that the compounds showed high antitumour activity and low toxicity. Studies are required about the effects of harmine derivatives on tumor apoptosis regulators.

The alkaloids

showed a protective effect against oxidative agents, presenting oxygen-dependent antioxidant and antimutagenic abilities.

The results are based on the use of B. caapi extract in the treatment of

Parkinson's disease.

It was possible to confirm the antimicrobial action of most of the plants tested,

although the values of MICs are considered high and with high variation. Traditional knowledge may contribute to the development of future antibiotics.

The results showed that the use of ayahuasca by rats during pregnancy and lactation reduces the anxiety of the offspring, but 
Thomas et al. 2013.

Ayahuasca-Assisted Therapy for Addiction: Results from a Preliminary

Observational Study in Canada

Therapeutic Effects of Ritual

Loizaga-Velder; Verres, 2014.

Szabo et al., 2014.

Osório et al., 2015.

Soares, 2015.

Estudo fitoquímico das folhas de Psychotria viridis

(Rubiaceae) e avaliação da atividade biológica de extratos e constituintes.

Barbosa et al., 2016.

Psychological and neuropsychological assessment of regular hoasca users.

Cruz; Nappo, 2018.

Is Ayahuasca an Option for the Treatment of Crack Cocaine Dependence?

Fontes, 2017. behavioral tests.

Follow-up of 12 participants in four days of ritual for six months after the retreat, collecting psychological and behavioral data.

Field observation and interview with 14 participants of the ayahuasca rituals.

Immunomodulatory activities of compounds present in $\mathrm{P}$. viridis in vitro were tested.

Six without placebo and doble blind! soft depressive volunteers participated in the study, who drank about $200 \mathrm{~mL}$ of decoction of the beverage and then carried out tests and interviews to assess the results.

An antimicrobial activity was tested using methanolic extract of $\mathrm{P}$. viridis in S. aureus, B. cereus, E. coli, K. oxytoca and $\mathrm{K}$. pneumoniae. 30 North American volunteers from the "Union of the Vegetal" group were evaluated after the ayahuasca rituals.

Also 27 individuals who did not ingest the drink were evaluated as a control group.

40 crack users who went through the ayahuasca ritual were evaluated throughan interview with the participants after the use of the beverage.

A double-blind
Statistically significant improvements in scales of hope, empowerment, and attention. Reduced use of alcohol, tobacco, and cocaine.

Half of the participants reported less interest in chemical substances.

Immunomodulatory action was observed in cytokines, interleukins, and

leukocytes, promoted by the substances.

Significant reductions of up to $82 \%$ were observed in the scores of depression assessment scales. No relationship between psychedelic effects and mood improvement was detected.

Only tryptamine, a precursor of DMT, found in $\mathrm{P}$. viridis leaves, showed antimicrobial activity against five bacteria.

The group showed a decrease in depression scores, a reduction in recent alcohol use, as well as an increase in the scores

of acceptability and accessibility.

The effects of improved self-esteem, social, and emotional awareness, which contributed to a reduction in the use of the drug, was reported.

A drop in the scores of the promoted high sensitivity to apprehension.

The findings suggest positive changes in the behavior and psychological characteristics of the participants.

More rigorous research is needed on the ayahuasca therapy.

When used appropriately, ayahuasca appears to be an effective tool for the treatment of chemical dependency.

The results point to a new biological action of

dimethyltriptamines

(DMT), which might act as inflammation regulators.

The results suggest that ayahuasca has anxiolytic and antidepressant effects in patients with depression.

Tryptamine has its antimicrobial activity reduced if methylated.

The findings indicate that the use of Ayahuasca is not associated with adverse neuropsychological effects and might have positive effects on mood and chemical dependency.

The findings indicate that the religious use of ayahuasca has therapeutic potential in chemical dependency. The results show 


\section{Macrothink Institute}

ayahuasca, suas bases neurais e relação com a experiência psicodélica.

Lafrance et al., Nourishing the Spirit: Exploratory 2017.

\section{Research on ayahuasca Experiences} along the Continuum of Recovery from Eating Disorders.

Talin; Sanabria, 2017.

Ayuasca's entwined efficacy: An ethnographic study of ritual healing from 'addiction'.

Santos et al., 2017.

Fisher et al., 2018. 2018. constituents from leaves and biological properties. clinical trial with 35 patients with unipolar depression in which a single

dose of ayahuasca or placebo was administered. A healthy group was also evaluated. of addiction recovery experiences of Italian and Brazilian groups the biological effects

dihydrophenylalanine

Santos et al., Long-term effects of ayahuasca in 2018. patients with recurrent depression: a 5-year qualitative follow-up.
Journal of Agricultural Studies

ISSN 2166-0379

2021, Vol. 9, No. 1

\author{
evaluation depression \\ scale was observed \\ compared with the \\ placebo.
}

the therapeutic value of ayahuasca in the treatment of depression. Interviews were conducted with 16 participants diagnosed with eating disorders who participated in the ayahuasca rituals.

Qualitative analysis in rituals, with observational study and interviews with the participants. Phytochemical evaluation was performed by

chromatography and of $P$. viridis species were analyzed.

The motor functions were tested in 8 marmosets treated with doses of B. caapi extract, harmine, selegiline, and (L-DOPA).

Interviews and follow-up of 46 participants of ayahuasca rituals were carried out during one year.

8 patients were

Most participants reported a reduction in thoughts and symptoms of eating disorders, as well as changes in body perception.

The effectiveness of ayahuasca in treating chemical dependency mixes various scopes. The care taken in rituals, where ayahuasca is collectively consumed, promotes a therapeutic role.

The DMT present in the species has inhibed acetylcholinesterase and B16F10 and 4T1 tumor cells.

The B. caapi extract showed an improvement in motor disability.

The intensity of the ayahuasca effects is not proportional to the therapeutic effects. Some informants have reported experiences in the treatment of chemical dependency.

interviewed 5 years after the study with17 patients with a history of depression, who ingested ayahuasca.

57 participants from Colombia and

Netherlands who participated in ayahuasca rituals
It was observed that the decrease in symptoms was restricted to only a few weeks, but that the experience was the most decrease in symptoms was restricted to only a few

weeks, but that the experience was the most important in the life of the participants.
Ayahuasca rituals show promise in the treatment of eating disorders.

The rituals have an important

therapeutic role, so that the practiced forms of care and group feeling help

in the recovery

from addiction. Selective cytotoxicity is an important property to be achieved in antitumor drugs.

The results showed that the

administration of only B. caapi has a mild antiparkinsonian effect, but it does not improve the response of

L-DOPA nor reduce dyskinesia.

Ayahuasca may be useful in the treatment of chemical dependency and is considered to have broad therapeutic potential. This might be based on remembrances.

It is the first follow-up study years after by the participants. Future studies are needed to validate the antidepressant and anxiolytic effects of ayahuasca. The work concluded that ayahuasca promotes improvements in ayahuasca ingestion 
were evaluated. They were evaluated one day before the ritual, one day after, and four weeks after.

Soler et al., 2015.

\section{Exploring the therapeutic potential of ayahuasca: acute intake increases mindfulness-related capacities.} Santos et al.
2011.

\author{
Autonomic, Neuroendocrine, and \\ Immunological \\ Effects of Ayahuasca: A \\ Comparative Study With \\ d-Amphetamine
}

Twenty-five participants in the ayahuasca rituals were evaluated, 24 hours before and after the use of the beverage, using questionnaires. 10 participants took in 3 experimental sessions, at least 1 week apart, taking 1 tablet containing either placebo or ayahuasca in a randomized double-blind model. important in the life of the participants

The use of ayahuasca resulted in improved attention by the participants.

Prolactin levels were significantly increased by ayahuasca but not by amphetamine, and cortisol was increased by both, with ayahuasca leading to the higher peak values. Ayahuasca and amphetamine induced similar time-dependent modifications in lymphocyte

subpopulations. Percent

CD4 and CD 3 were

decreased, whereas natural killer cells were increased. affection and cognitive thinking in non-pathological users, showing the potential of the beverage in treatments of mental disorders, such as depression.

The findings indicate that ayahuasca has therapeutic potential, especially regarding attention.

ayahuasca displayed moderate sympathomimetic effects, significant neuroendocrine stimulation, and a time-dependent modulatory effect on cell-mediated immunity.

\section{Conclusion}

The present work demonstrated that, although there are studies on the therapeutic potentials of ayahuasca, there is still a scarcity of studies that verify the criteria of validity, safety and efficacy of the therapeutic use of B. caapi and P. viridis, components of ayahuasca.

Knowledge about medicinal plants is essential for their use in different alternative therapies. In the current scenario of literature, studies focus on the area of neuropsychology, addressing the decoction of ayahuasca as a form of therapy for neurological and neuromotor disorders. In addition, antimicrobial, antiparasitic, immunomodulatory and antioxidant properties have been reported. However, although the knowledge about medicinal plants today is vast, more and more research is needed, since these plants are often used incorrectly and, consequently, present a great risk due to the accumulation of active substances. Thus, one must evaluate the efficacy and safety of ayahuasca composed from Banisteriopsis Caapi and Psychotria Viridis, in addition to its other constituent plant species, in order to use it as an therapeutic alternative, especially in the population from which traditional knowledge about this beverage originates.

\section{Acknowledgements}

The authors would like to thank UNIPAR, Araucaria Foundation and the CAPES for funding this research. 


\section{References}

(2006a). Decreto n. ${ }^{o}$ 5813, de 22 de junho de 2006. Aprova a Política Nacional de Plantas Medicinais e Fitoterápicos e dá outras providências. Brasília: Diário Oficial da União. (2006b). Portaria n. ${ }^{\circ}$ 971, de 03 de maio de 2006. Aprova a Política Nacional de Práticas Integrativas e Complementares (PNPIC) no Sistema Único de Saúde. Brasília: Ministério da Saúde.

(2009). Programa Nacional de Plantas Medicinais e Fitoterápicos. Brasília: Ministério Da Saúde. Retrieved from http://portalsaude.saude.gov.br/images/pdf/2015/janeiro/05/programa-nacional-plantas-medic inaisfitoter--picos-pnpmf.pdf

(2014). Resolução da Diretoria Colegiada - RDC nº 26, de 13 de maio de 2014. Dispõe sobre o registro de medicamentos fitoterápicos e o registro e a notificação de produtos tradicionais fitoterápicos. Brasília: Diário Oficial da União Retrieved from http://bvsms.saude.gov.br/bvs/saudelegis/anvisa/2014/rdc0026_13_05_2014.pdf

. (2008). The globalization of ayahuasca: Harm reduction or benefit maximization?

International Journal of Drug Policy, 19(4), 297-303.

https://doi.org/10.1016/j.drugpo.2006.11.001

Argentina. (1971). Ley n 19.303 de 11 de outubro de 1971. Buenos Aires Retrieved from http://www.anmat.gov.ar/webanmat/Legislacion/Medicamentos/ley19303.pdf

Barbosa, P. C. et al. (2016). Psychological and neuropsychological assessment of regular hoasca users. Compr Psychiatry, 71, 95-105. https://doi:10.1016/j.comppsych.2016.09.003

Brasil. (2004). Resolução n. 4, de 04 de novembro de 2004. Brasília: Conselho Nacional Antidrogas.

Brierley, D. I. and Davidson, C. (2012). Developments in harmine

pharmacology--implications for ayahuasca use and drug-dependence treatment. Prog

Neuropsychopharmacol Biol Psychiatry, 39(2), 263-272.

https://doi:10.1016/j.pnpbp.2012.06.001

Bussmann, R. W. et al. (2010). Minimum inhibitory concentrations of medicinal plants used in Northern Peru as antibacterial remedies. J Ethnopharmacol, 132(1), 101-108.

https://10.1016/j.jep.2010.07.048

Cahal, D. A. (1974). Misuse of Drugs Act 1971. British Medical Journal, 1(5897), 70-72. https://doi:10.1136/bmj.1.5897.70

Callaway, J. C., \& Grob, C. S. (1998). Ayahuasca preparations and serotonin reuptake inhibitors: a potential combination for severe adverse interactions. J Psychoactive Drugs, 30(4), 367-369. https://doi:10.1080/02791072.1998.10399712 
Callaway, J. C., Brito, G. S., \& Neves, E. S. (2005). Phytochemical analyses of Banisteriopsis caapi and Psychotria viridis. J Psychoactive Drugs, 37(2), 145-150. https://doi:10.1080/02791072.2005.10399795

Chen, Q. et al. (2005). Antitumor and neurotoxic effects of novel harmine derivatives and structure-activity relationship analysis. Int J Cancer, 114(5), 675-682.

https://doi:10.1002/ijc.20703

Cruz, J. I., \& Nappo, S. A. (2018). Is Ayahuasca an Option for the Treatment of Crack Cocaine Dependence? J Psychoactive Drugs, 50(3), 247-255.

https://doi:10.1080/02791072.2018.1447174

España. (2004). Orden SCO/190/2004, de 28 de enero, por la que se establece la lista de plantas cuya venta al público queda prohibida o restringida por razón de su toxicidad. Retrieved from Madrid: https://www.boe.es/boe/dias/2004/02/06/pdfs/A05061-05065.pdf

Ferreira, L. O., \& Osório, P. (2007). Medicina tradicional indígena em contextos: anais da primeira reunião de monitoramento. Brasília: Projeto Virgus II/Funasa

Fisher, R. et al. (2018). The effect of Banisteriopsis caapi (B. caapi) on the motor deficits in the MPTP-treated common marmoset model of Parkinson's disease. Phytother Res, 32(4), 678-687. https://doi:10.1002/ptr.6017

Fontes, F. P. X. d. (2017). Os efeitos antidepressivos da ayahuasca, suas bases neurais e relação com a experiência psicodélica. (Doutorado), Universidade Federal do Rio Grande do Norte, Natal. Retrieved from https://repositorio.ufrn.br/jspui/handle/123456789/24156

Garrido, R. G., \& Sabino, B. D. (2009). Ayahuasca: entre o legal e o cultural. Saúde, Ética \& Justiça, 14(2), 44-53. https://doi.org/10.11606/issn.2317-2770.v14i2p44-53

Horák, M., Hasíková, L., \& Verter, N. (2018). Therapeutic Potential Ascribed to Ayahuasca by Users in the Czech Republic. J Psychoactive Drugs, 50(5), 430-436.

https://doi:10.1080/02791072.2018.1511878

Labate, B. (2004). A literatura brasileira sobre as religiões ayahuasqueiras. In Labate BC. O uso ritual da ayahuasca (pp. 231-273). Campinas: Mercado de Letras Edições e Livraria.

Lafrance, A. et al. (2017). Nourishing the Spirit: Exploratory Research on Ayahuasca Experiences along the Continuum of Recovery from Eating Disorders. J Psychoactive Drugs, 49(5), 427-435. https://doi.org/10.1080/02791072.2017.1361559

Loizaga-Velder, A., \& Verres, R. (2014). Therapeutic effects of ritual ayahuasca use in the treatment of substance dependence--qualitative results. J Psychoactive Drugs, 46(1), 63-72. https://doi.org/10.1080/02791072.2013.873157

Mamede, M. C. H. (2015). Banisteriopsis. In Lista de espécies da flora do Brasil. Jardim Botânico do Rio de Janeiro.

McIlhenny, E. H. et al. (2009). Direct analysis of psychoactive tryptamine and harmala alkaloids in the Amazonian botanical medicine ayahuasca by liquid 
chromatography-electrospray ionization-tandem mass spectrometry. J Chromatog, 1216(51), 8960-8968. https://doi.org/10.1016/j.chroma.2009.10.088

McKenna, D. J. (2004). Clinical investigations of the therapeutic potential of ayahuasca: rationale and regulatory challenges. Pharmacology \& therapeutics, 102(2), 111-129. https://doi.org/10.1016/j.pharmthera.2004.03.002

Meneguelli, A. Z. et al. (2020). Avaliação etnofarmacológica e botânica de plantas medicinais utilizadas pela comunidade indígena da Amazônia brasileira. Interações (Campo Grande) , 21(3), 633-645. https://doi.org/10.20435/inter.v21i3.2926

Moura, D. J. et al. (2007). Antioxidant properties of beta-carboline alkaloids are related to their antimutagenic and antigenotoxic activities. Mutagenesis, 22(4), 293-302. https://doi.org/10.1093/mutage/gem016

Netherlands. (1928). Opiumwet: Wet van 12 mei 1928, tot vaststelling van bepalingen betreffende het opium en andere verdoovende middelen. Orange-Nassau: Overheid Retrieved from https://wetten.overheid.nl/BWBR0001941/2009-07-01

Norge. (2013). Forskrift om narkotika (narkotikaforskriften). Oslo Retrieved from https://lovdata.no/dokument/SF/forskrift/2013-02-14-199

Nunes, A. et al. (2016). Effects of Ayahuasca and its Alkaloids on Drug Dependence: A Systematic Literature Review of Quantitative Studies in Animals and Humans. $J$ Psychoactive Drugs, 48, 1-11. https://doi.org/10.1080/02791072.2016.1188225

Oliveira, C. D. R. d. et al. (2011). Neurobehavioral, reflexological and physical development of Wistar rat offspring exposed to ayahuasca during pregnancy and lactation. Revista Brasileira de Farmacognosia, 21, 1065-1076.

https://doi.org/10.1590/S0102-695X2011005000170

Osório, F. d. L. et al. (2015). Antidepressant effects of a single dose of ayahuasca in patients with recurrent depression: a preliminary report. Brazilian Journal of Psychiatry, 37, 13-20. https://doi.org/10.1590/1516-4446-2014-1496

Palhano-Fontes, F. et al. (2018). Rapid antidepressant effects of the psychedelic ayahuasca in treatment-resistant depression: a randomized placebo-controlled trial. Psychological Medicine, 49(4), 655-663. https://doi.org/10.1017/S0033291718001356

Pomilio, A. B. et al. (1999). Ayahoasca: an experimental psychosis that mirrors the transmethylation hypothesis of schizophrenia. J Ethnopharmacol, 65(1), 29-51.

https://doi.org/10.1016/S0378-8741(98)00163-9

Portugal. (2000). Lei no 30/2000, de 29 de novembro de 2000. Lisboa: Diário da República Retrieved from https://dre.pt/application/conteudo/599720.

Samoylenko, V. et al. (2010). Banisteriopsis caapi, a unique combination of MAO inhibitory and antioxidative constituents for the activities relevant to neurodegenerative disorders and 
Parkinson's disease. J Ethnopharmacol, 127(2), 357-367.

https://doi.org/10.1016/j.jep.2009.10.030

Santos, R. G. D. et al. (2018). Long-term effects of ayahuasca in patients with recurrent depression: a 5-year qualitative follow-up. Archives of Clinical Psychiatry (São Paulo), 45, 22-24. https://doi.org/10.1590/0101-60830000000149

Santos, R. G. D., Moraes, C. C. D. \& Holanda, A. (2006). Ayahuasca e redução do uso abusivo de psicoativos: eficácia terapêutica? Psicologia: Teoria e Pesquisa, 22, 363-370. https://doi.org/10.1590/S0102-37722006000300014

Santos, R. G. et al. (2007). Effects of ayahuasca on psychometric measures of anxiety, panic-like and hopelessness in Santo Daime members. J Ethnopharmacol, 112(3), 507-513. https://doi.org/10.1016/j.jep.2007.04.012

Santos, R. G. et al. (2011). Autonomic, neuroendocrine, and immunological effects of ayahuasca: a comparative study with d-amphetamine. J Clin Psychopharmacol, 31(6), 717-726. https://doi:10.1097/JCP.0b013e31823607f6

Schwarz, M. J. et al. (2003). Activities of extract and constituents of Banisteriopsis caapi relevant to parkinsonism. Pharmacol Biochem Behav, 75(3), 627-633.

https://doi:10.1016/s0091-3057(03)00129-1

Shi, C. C., Liao, J. F., \& Chen, C. F. (2001). Comparative study on the vasorelaxant effects of three harmala alkaloids in vitro. Jpn J Pharmacol, 85(3), 299-305.

https://doi:10.1254/jjp.85.299

Soares, D. B. (2015). Estudo fitoquímico das folhas de Psychotria viridis (Rubiaceae) e avaliação da atividade biológica de extratos e constituintes. (Mestrado), UFMG, Minas Gerais. Retrieved from http://hdl.handle.net/1843/SFSA-9XAPGP

Soares, D. B. S. et al. (2017). Psychotria viridis: Chemical constituents from leaves and biological properties. Anais da Academia Brasileira de Ciências, 89, 927-938.

https://doi.org/10.1590/0001-3765201720160411

Soler, J. et al. (2015). Exploring the therapeutic potential of Ayahuasca: acute intake increases mindfulness-related capacities. Psychopharmacology (Berl), 233(5), 823-829. https://doi:10.1007/s00213-015-4162-0

Sweden. (1968). Narkotikastrafflag (1968:64). Helgeandsholmen: Regeringskansliets rättsdatabaser Retrieved from http://rkrattsbaser.gov.se/sfst?bet=1968:64

Szabo, A. et al. (2014). Psychedelic N,N-Dimethyltryptamine and

5-Methoxy-N,N-Dimethyltryptamine Modulate Innate and Adaptive Inflammatory Responses through the Sigma-1 Receptor of Human Monocyte-Derived Dendritic Cells. PLOS ONE, 9(8), e106533. https://doi:10.1371/journal.pone.0106533 


\section{Macrothink}

Journal of Agricultural Studies

ISSN 2166-0379

2021, Vol. 9, No. 1

Talin, P., \&Sanabria, E. (2017). Ayahuasca's entwined efficacy: An ethnographic study of ritual healing from 'addiction'. Int J Drug Policy, 44, 23-30.

https://doi:10.1016/j.drugpo.2017.02.017

Taylor, C., Gomes, M., \& Zappi, D. (2015). Psychotria in lista de espécies da flora do brasil. Jardim Botânico do Rio de Janeiro.

Thomas, G. et al. (2013). Ayahuasca-assisted therapy for addiction: results from a preliminary observational study in Canada. Curr Drug Abuse Rev, 6(1), 30-42.

https://doi:10.2174/15733998113099990003

Tupper, K. (2002). Entheogens and Existential Intelligence: The Use of Plant Teachers as Cognitive Tools. Canadian Journal of Education, 27, 499-516. doi:10.2307/1602247

United States. (2019). N,N-DIMETHYLTRYPTAMINE (DMT). Springfield: Drug \& Chemical Evaluation Section Retrieved from

https://www.deadiversion.usdoj.gov/drug_chem_info/dmt.pdf

UNODC. (2013). The International Drug Control Conventions. New York: United Nations Office on Drugs and Crime.

Uruguay. (1998). Ley $\mathrm{N}^{\mathrm{o}} 17.016$ estupefacientes dictanse normas referentes a estupefacientes ysustancias que determinen dependencia fisica o psiquica. Montevidéu: Poder Legislativo.

Uthaug, M. V. et al. (2018). Sub-acute and long-term effects of ayahuasca on affect and cognitive thinking style and their association with ego dissolution. Psychopharmacology (Berl), 235(10), 2979-2989. https://doi:10.1007/s00213-018-4988-3

Vetrulli, M. (2011). Comando Carabinieri per la tutela della salute. Perúgia Retrieved from https://www.bialabate.net/wp-content/uploads/2008/08/Nota_Ministero_Della_Salute_2010.p df

Wang, Y. H. et al. (2010). Composition, standardization and chemical profiling of Banisteriopsis caapi, a plant for the treatment of neurodegenerative disorders relevant to Parkinson's disease. J Ethnopharmacol, 128(3), 662-671.

https://doi:10.1016/j.jep.2010.02.013

World Healt Organization. (1998). Regulatory situation of herbal medicines: a worldwide review. Geneva: World Health Organization Retrieved from https://apps.who.int/medicinedocs/pdf/whozip57e/whozip57e.pdf

\section{Copyright Disclaimer}

Copyright for this article is retained by the author(s), with first publication rights granted to the journal.

This is an open-access article distributed under the terms and conditions of the Creative Commons Attribution license (http://creativecommons.org/licenses/by/4.0/). 